\title{
方向性けい素鋼板を使用した磁気式 ロードセル
}

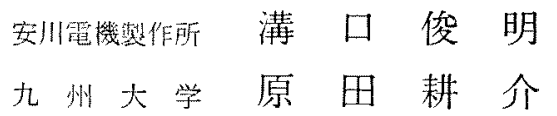

\section{1. まえがき}

磁参ひずみ就果夺利用した磁気式ロードセ儿は，抵 䇄線さずみゲージ式ロードセルに比校して出力が大き く過目荷にも強いなどの特長があり，古くから使用さ れてきた。この整の磁気式ロードセルには徉来, 变压 器形(1)(2) 上磁気增幅器形(3)〈(4) とリアクトル形(5)(6) の㮔 類があるが，いずれもをの動作原理についての定量的 な解析結果はこれむで発表されていない。

本稿では方向性けい絜鋼板を使用したりアクトル形 ロードセルの解析を行なうために，まず，単結晶モデ ルを使用して応力と磁化特性との間の近仅的な関係式 存求めている。次に，可舄和りアクトル上の相似性上 磁心の形状效果を考慮に入れたりアクトル形ロードセ ルの等価回路を示し，伝達特性やその比例限界，直線

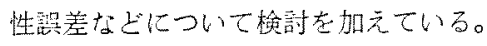

\section{2. 外部応力による磁化曲線变化の解析}

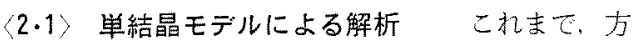
向性けい奉鋁板口応力下の磁気特性や鉄損については 多くの㬰測結果方゙発素されているが，ロードセルの基 本原理しして利用できるような理諭的な解析結果はあ まりみられな⿰力た。磁気異方性を有する磁性体口応 力下の磁気特性が, 主上して, 磁気異方性エネルギー, 磁気弾性エネルギー，磁化エネルギ一の3つのエネル ギーによって左在さ机るとと代前加ら知られていた

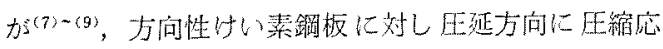

\footnotetext{
Magnetic Load Cell with Oriented Silicon-Iron Steel Laminations. By Toshiahi Mizoguchi, Member (Yaskawa Electric Co., Ltd.) \& Kosuke Harada, Member (Faculyof Engineering, Kyushu University).

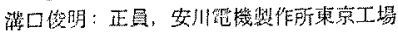

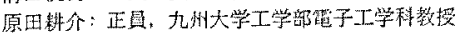

力上磁界老加えた場合の磁化曲線に閣しては理想状態 の仮定の下に提婪されたモデル(5)がある。

本節では，このモデル在拡張して任意方向加ら圧縮 応力上磁界を加元た場合の㐫力之瓶化曲線との間の一 般的な関係式在求める。ここては，力问性けい素鋼板 が压延方向に〔100\}軸老古，压延面を〔011\} 上する 単結晶モデルを仮定し，圧延方问に刘して任意の前度 $\gamma$ の方向加和縮応力 $\sigma$ 之磁界 $H$ を加えた場合につ いて考察する。この場合，本稿ては方向性けい素鋼板 在栈層して用いるので，厚さ方向の反磁界は無視でき るものと仮定した。

結晶の磁気異方性エネルギーを $E_{\kappa}$, 応力による磁 気弾性エネルギーを $E_{\sigma}$ ，磁界による磁化エネルギー を $E_{H}$ 上すると，各エネルギーは一般に知ら机てい る下記の式で与えられる。

$$
\begin{aligned}
& E_{K}=K_{1}\left(\alpha_{1}^{2} \alpha_{2}^{2}+\alpha_{2}^{2} \alpha_{3}{ }^{2}+\alpha_{3}^{2} \alpha_{1}^{2}\right) \\
& +K_{2} \alpha_{1}{ }^{2} \alpha_{2}{ }^{2} \alpha_{3}{ }^{2} \\
& E_{\sigma}=\lambda \sigma \\
& \lambda=(3 / 2) \lambda_{100}\left(\alpha_{1}^{2} \beta_{1}{ }^{2}+\alpha_{2}{ }^{2} \beta_{2}{ }^{2}\right. \\
& \left.+\alpha_{3}{ }^{2} \beta_{3}{ }^{2}-1 / 3\right)+3 \lambda_{111}\left(\alpha_{1} \alpha_{2} \beta_{1} \beta_{2}\right. \\
& \left.+\alpha_{2} \alpha_{3} \beta_{2} \beta_{3}+\alpha_{3} \alpha_{1} \beta_{3} \beta_{1}\right) \\
& E_{H}=-J_{S} H \cos \theta_{J H}
\end{aligned}
$$

但し, $K_{1}^{*}, K_{2}$ : 磁気異方性定敉， $\lambda_{100}, \lambda_{111}$ ：磁 わい定数， $\left(\alpha_{1}, \alpha_{2}, \alpha_{3}\right)$ : 自登磁化 $J_{S}$ 方向余 弦, $\left(\beta_{1}, \beta_{2}, \beta_{3}\right)=(\cos \gamma, 1 / \sqrt{2} \sin \gamma, 1 / \sqrt{2} \sin$ $\gamma)$ : 応力 $\sigma$ 方向余弦, $\cos \theta_{J H}=\sum \alpha_{i} \beta_{i}$

$J_{S}$ 乙 $H$ のなす角度 $\theta_{J H}$ の余弦

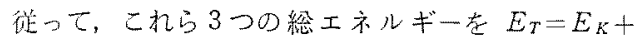
$E_{\sigma}+E_{H}$ とす机，与えられた大きさの応力 $\sigma$ ，磁界 $H$ に対して $E_{T}$ 加最小となるような自発磁化 $J_{S}$ の 方向を求的ることより㐫力下の磁化曲線在求好るこ とが可能である。しかしながら，実際には，けい蒵銅 
の結晶異方性が非常に大きいので，応打が政性限界内

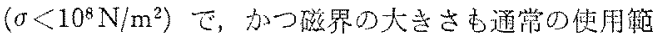
用 $\left(H<2 \times 10^{3} \mathrm{~A} / \mathrm{m}\right)$ では， $K_{1} \gg \lambda_{100} \sigma, K_{1} \gg J_{S} H$ であ って，自発磁化の方向位化容易方向である (100)， [010]，(001] 万向，あるいは己の極く近傍のみを向い ている上考えることができる。このてとを利用すれば

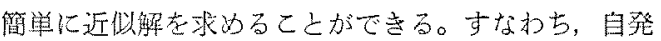
斑化 $J_{S}$ の方向余登は $\theta$ を〔100〕方向となす角とす 万上近仪的に $\left(\alpha_{1}, \alpha_{2}, \alpha_{3}\right)=(\cos \theta, \sin \theta, 0)$ 上霄ける 0 む， $E_{T}=E_{T}(\theta, H, \sigma)$ 乙葿くこにしすれば， $E_{T}$ を最

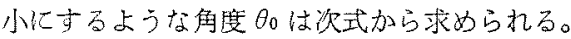

$$
\theta_{0}=\left\{\begin{array}{c}
0, E_{T}(0, H, \sigma)-E_{T}(\pi / 2, H, \sigma)<0 \\
\pi / 2, E_{T}(0, H, \sigma)-E_{T}(\pi / 2, H, \sigma)>0
\end{array}\right.
$$

$$
\begin{aligned}
E_{T} & (0, H, \sigma)-E_{T}(\pi / 2, H, \sigma) \\
= & \frac{3}{2} \lambda_{100} \sigma\left(\cos ^{2} \gamma-\frac{1}{2} \sin ^{2} \gamma\right) \\
& -J_{s} H\left(\cos \gamma-\frac{1}{V} \sin \gamma\right)
\end{aligned}
$$

(6) 式加ら， $E_{T}\left(0, H_{T}, \sigma\right)=E_{T^{\prime}}\left(\pi / 2, H_{T}, \sigma\right) な る$ $H_{T}$ 大求めるし次式力゙得ら机る。

$$
H_{T}=\frac{3}{2} \cdot \frac{\lambda_{100}}{J_{S}}\left(\frac{1}{V 2} \sin \gamma+\cos \gamma\right) \sigma \ldots \ldots
$$

但 $U, \cos \gamma \neq(1 / \sqrt{2}) \sin \gamma$

ここで，HTは，第 1 図に示すように，磁界花徐々に 璔加又は隇少させるときに磁化の強さが急に变化する 部分の酷界の強さを示泉ののである。

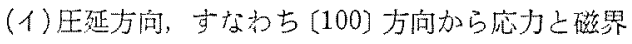

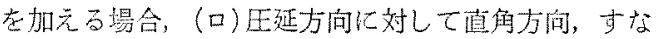

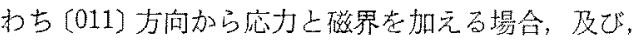
(八)〔111〕方向加ら応力上磁界索加光万場合の祭場含

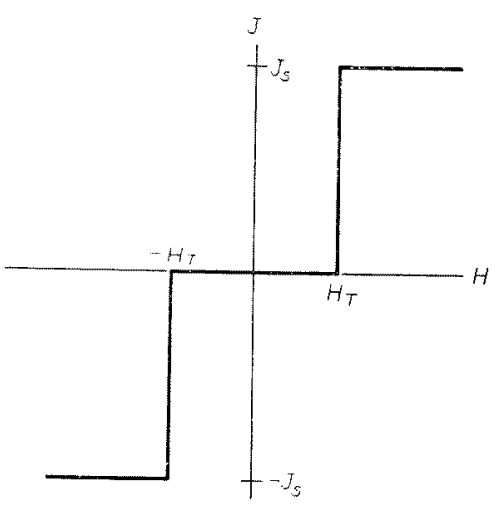

第 1 因 シリコン鉄単絬晶の理想的磁化曲線

Fig. 1. Ideal magnetization curves of single crystals.
について苍えるよ，それぞれ $\gamma=0^{\circ}, \gamma=90^{\circ}, \gamma=55^{\circ} に$ 相当するから，H

〔100]方角 $H_{T}=\frac{3}{2} \cdot \frac{\lambda_{100}}{J_{S}} \sigma$

〔011〕方向 $H_{T}=\frac{3}{2 \sqrt{2}} \cdot \frac{\lambda_{100}}{J_{S}} \sigma$

[111]方向 $H_{T}$ は存在しない。 一般に常用されている単任しして，心力 $\sigma\left(\mathrm{N} / \mathrm{m}^{2}\right) の$ 代りに $\sigma^{\prime}=9.8 \times 10^{6} \sigma\left(\mathrm{kg} / \mathrm{mm}^{2}\right)$ を，磁界の強さH $(\mathrm{A} / \mathrm{m})$ の代りに $H^{\prime}=4 \pi H \times 10^{-3}(\mathrm{Oe})$ 使用して 3 $\%$ シリコン鉄について訲筑すると, 定数 $J_{S}=2.0(\mathrm{~Wb} /$ $\left.\mathrm{m}^{2}\right), \lambda_{100}=26 \times 10^{-6}$ 老(8),(9)式へ代入してそれぞ れ次式加得ら机る。

$$
\begin{array}{ll}
\text { (100] 万问 } H_{T} \fallingdotseq 2.4 \sigma^{\prime}(\mathrm{Oe}) \\
\text { (011) 万向 } H_{T}^{\prime} \fallingdotseq 1.7 \sigma^{\prime}(\mathrm{Oe})
\end{array}
$$

(7) （11) 式は，第 1 図のような応力下の磁化曲線 の $H_{T}$ (又は $H_{T^{\prime}}$ ) が王䋨芯力 $\sigma$ (又は $\sigma^{\prime}$ ) 比例す るこしを示して招り，リアクトル形ロードセルの基本 しなる式である。

〈2.2〉実験結果上考察＼cjkstart約 3\%のシリコンを含

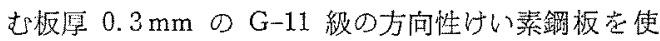
用し，乙机第2国の形状に打抜さ，空素ふ九い気中 $800^{\circ} \mathrm{C}$ で2時間焼鈍した後，積屬，接着して磁心を製 作した。磁心はそれぞ机 $\gamma$ が $0^{\circ}, 90^{\circ}, 55^{\circ}$ になってい る3種類在用意した。

第 3 因(a)〜 (c) の各奏線は，第 2 図の磁心に上下 方向の区縮応力在加元た場合の直流磁化曲線の変化を 実测したものである。ここで，圈中の櫛軸目盛は応力 印加部分の平均磁路長 $l=\left(l_{1}+l_{2}\right) / 2$ 加方求めた值です る。（a）图，(b)图ではいずれ古応力の增加上共に磁 化曲䋩が左右八移嘭しているが，(c) 図の $\gamma=55^{\circ}$ で は任とんじ变化していない。これらの傾间は笔結晶モ

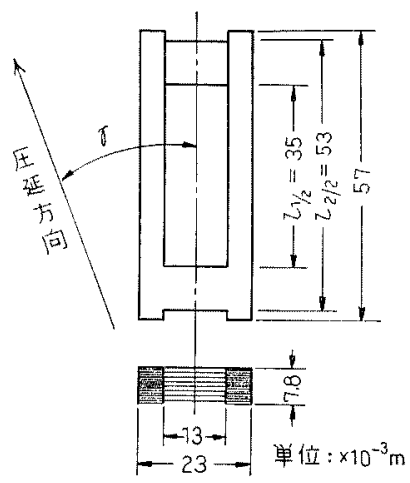

第 2 図磁心の形状

Fig. 2. Magnetic cores geometry. 

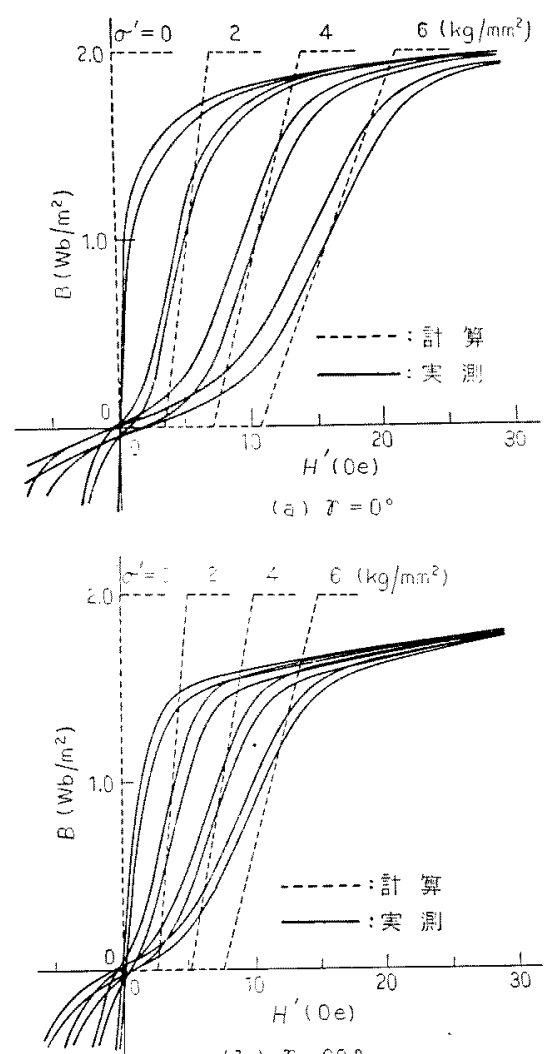

(b) $7=90^{\circ}$

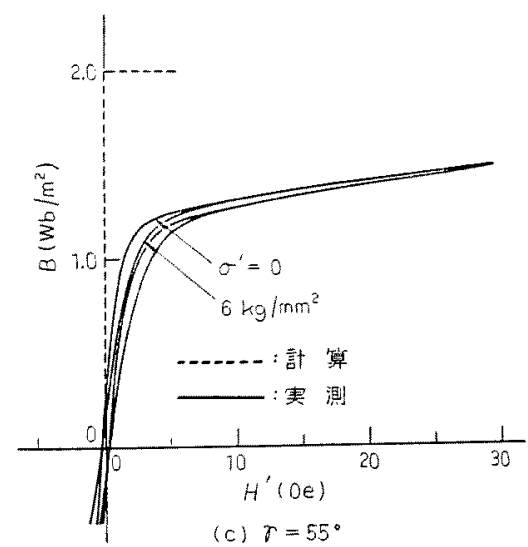

第3图 磁心口酳化出線に対与る応力口影䇺

Fig. 3. Effect of compressive stress on magnetization curves of cores.

デルによる解析䜌累と主くあっている。

実測された磁化罡線か第1図と異なりなるらかなこ う配老持っている医因ししては, 主として以下の3点 加若えりれる。

中であ一荏大きな原因として考えられるのは磁心の 形状効果によるもので，実際の磁心加有限の大きさた

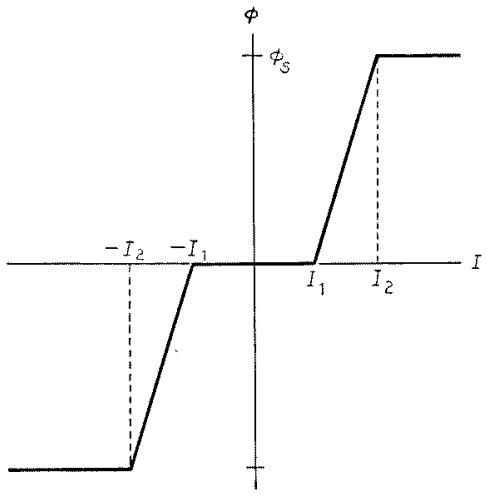

第 4 図 磁心の理想的 $\phi-I$ 曲線

Fig. 4. Ideal $\phi-I$ curves of cores.

持つことに上り $\phi-I$ 特性にこう配が表勋机ることで ある。例えば，第2図の磁心が第 1 図のような磁化特 性を持つ結晶の集合でできていると仮定し，磁心の応 力田加部分におけ万最短磁路長老 $l_{1}$, 最長磁路舆を $l_{2}$ 上すると第4図のような磁化特性が得られる。ここ こ，これぎれ $I_{1}, I_{2}$ は次式で与えられる。

$$
\begin{aligned}
& I_{1}=\left(l_{1} / N_{G}\right) H_{T} \\
& I_{2}=\left(l_{2} / N_{G}\right) H_{T}
\end{aligned}
$$

但し， $N_{G}$ : 磁心に巻かれた篦線の巻数。

(12)，(13)式加次の関係が得られる。

$$
I_{2} / I_{1}=l_{2} / l_{1}
$$

第 3 図（a），(b)には，この実験に使用した磁心の定 数, $l_{1}=70 \times 10^{-3} \mathrm{~m}, l_{2}=106 \times 10^{-3} \mathrm{~m}$ 在考虑して求め た磁化特性点線て不してある。实測值と計算值上の 間には，かなりの一致性加みられる。第 4 囷のI $I_{2}$ との間の磁化特性は直線で示してあるが，磁心の形 状によっては異なった幽線となることが想される。

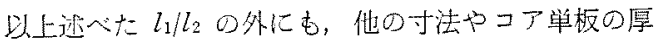
さ, 積層厚さなどが北状效果として磁化特性に複雑に

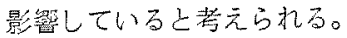

第2 の原因は，結晶配列の不完全さによるものであ

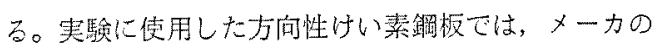

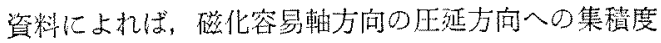
は $10^{\circ}$ 以外が $75 \%$ て平均 $7^{\circ}$ ぐらいと推定される。 多結晶性磁性体の磁化率が応力に反比例する ${ }^{(10)} こ と$ を考えると，この結晶配列の不完全さにより多少この 性貿加重显されているものと考えられる。

第3は応力分布の非一㴍性によるもので，灾力集中 などにより磁心内部の広力分行が一様でない場合には 各部の酳化特性が同一にならないために，磁化曲線を なからかにする原因となる。

最近ではり単結鼠性の㕍れた方向性けい素鋼板屯 
市服されているので，このような材料で形状効果や応 力集中をでさるだけ小さくするように磁心を製作する こ上ができ机は，第 1 図に示すような単結晶の理想的 磁化曲線により近いものが得られるであるう。

\section{3. リアクトル形ロードセル}

$\langle 3 \cdot 1\rangle$ 応力之直流制御電流の相似性単結晶モ デルによる解析結果によれば，応力印加時の磁心が第 1 图の上うな酳化特性変化を示士ことが明らかとなっ

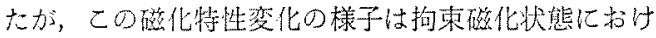
る可飽和りアクトル(11)で, 直流制御電流老パラメータ とした場合の磁化特性変化之類似して扔り，両者は回 路的に同様な取扱い方がでさる(12)。

第5四（a)はリアクトル形ロードセルの基本的な回 路構成である。 $N_{G}$ は煫心に巻かれたゲート巻線の巻 数, $e$ は電源電圧, $R_{0}$ はゲート巻線の抵抗 $R_{G}$ 及び 負荷抵抗夻含的太出力回路の全抵抗， $i$ は出力回路考

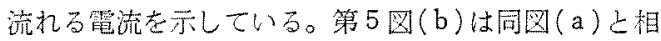
似な可蚫和りアクトルの回路構成で， $N_{C}$ は磁心の制 御巻線の巻数, $I_{C}$ 泣制御電流, $L$ 汁十分大きなインダ クタンス, $2 e$ は電源電圧， $2 R_{0}$ は出力回路の全抵抗

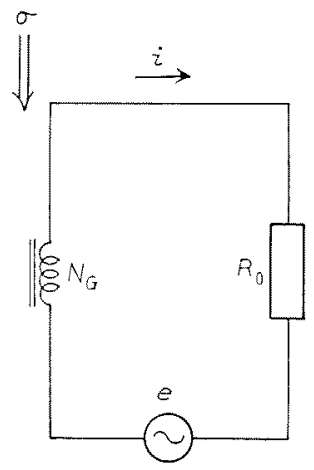

(a) リアクトル猳ロート゚セル

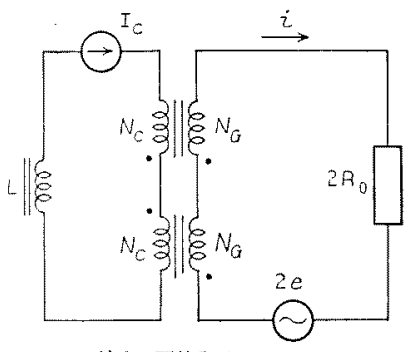

(b) 可鴒和リアクトル

第5 四 リアクトル形ロードセルの基本回路 とこれに相似な可飽和りアクトル回路

Fig. 5. Fundamental circuit of a reactor type load cell and an analogical saturable reactor circuit to the former.
综 1 表 互換 表

Table 1. Analogy between constants.

\begin{tabular}{|c|c|c|}
\hline & 钧 5 园(a) & 第 5 圆(b) \\
\hline 等佂制御管流 & $\left(l / N_{G}\right) H_{T}$ & $\left(N_{C} / N_{G}\right) I_{C}$ \\
\hline 然层荷蚫和電正 & $E_{s 0}$ & $2 E_{s 0}$ \\
\hline 钧和磁束密宏 & $E_{s}$ & $2 B_{s}$ \\
\hline 回路の抵莯 & $R_{0}$ & $2 R_{0}$ \\
\hline
\end{tabular}

を示している。すなわち，（a）図の回路て応力 $\sigma を$ 立变数とした場合の出力電流 $i$ の变化の様子は, 直流 制御電流 $I_{C}$ を独立变数上した(b)図の可飽和りアク トル回路の場合上同様にして求为ることができる。こ の場合の両回路の互換性老第 1 表化示す。但し， $l$ は

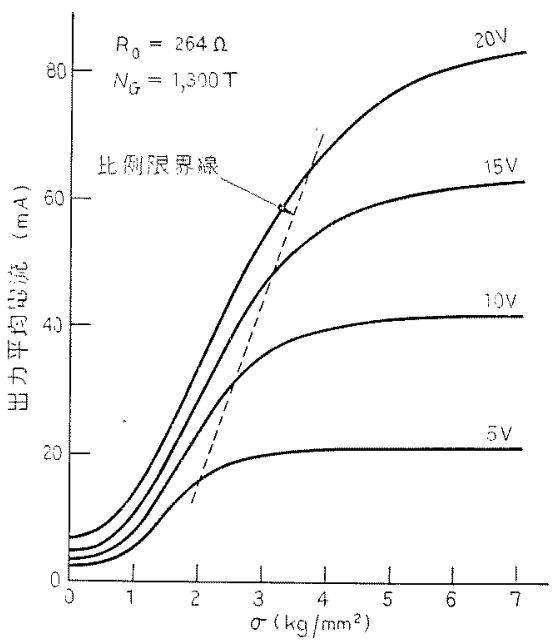

(a)リアクトル指ロードょル

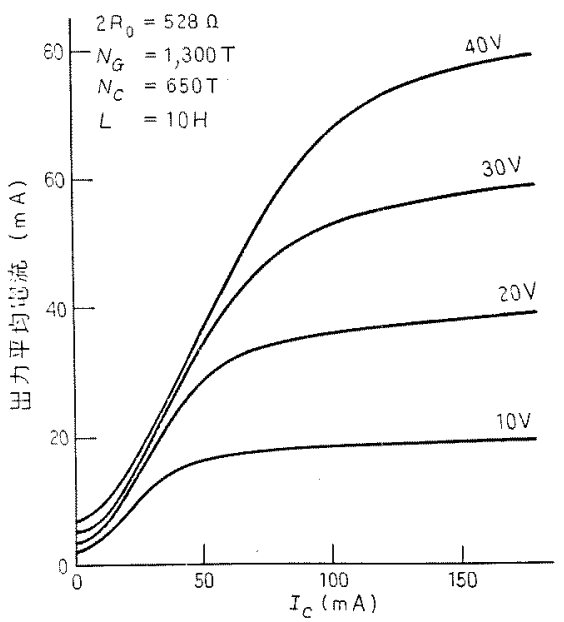

（b）可䝭梱りアタトル

第 6 図 制御特性

Fig. 6. Transfer characteristics. 


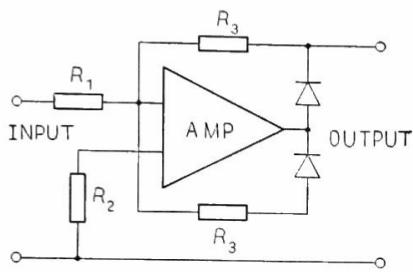

第 7 図整流回路

Fig. 7. Rectifier circuit.

応力印加部分の磁心の平均磁路長である。

第 5 図 (a)と (b)の回路に対して同一条件下におけ る制御特性をそれぞれ第 6 図 $(a)$ と ( b ) に示す。磁心 は第2 図の形状で圧延方向 $(\gamma=0)$ に打抜いたものを 使用している。又, 出力平均電流の测定には第 7 図の 回路を使用し, 整流器の微小電流における非直線性の 影響を受けないようにしている。

又, 第 8 図には，第 5 図(a)と（b)の回路がそれぞ れ比例領域において，第 1 表の互換条件を満たすよう

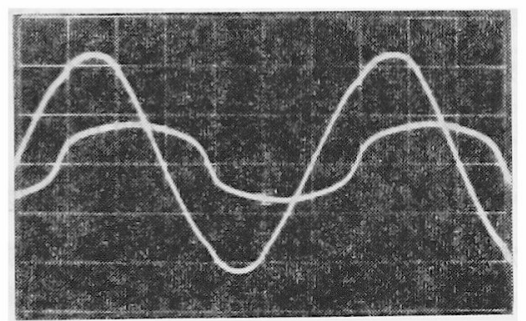

(a) リアクトル形ロードセル $R_{O}=128 \Omega, \sigma=6 \mathrm{~kg} / \mathrm{mm}^{2}$ $e=15 \mathrm{~V}, Y=10 \mathrm{~V} / \mathrm{div}, f=60 \mathrm{~Hz}$

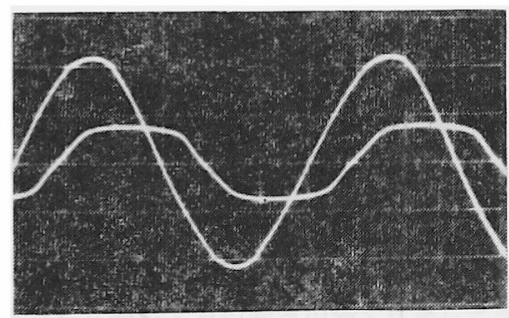

(b) 可飽和リアクトル $2 R_{0}=256 \Omega, \quad I_{C}=150 \mathrm{~mA}$ $2 e=30 \mathrm{~V}, \quad Y=20 \mathrm{~V} /$ div,$\quad f=60 \mathrm{~Hz}$

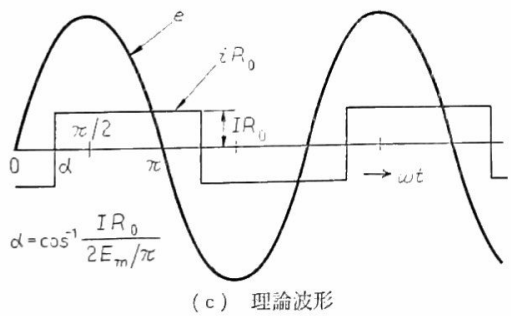

第 8 図励磁電压と出力電圧の波形

Fig. 8. Oscillograms of magnetizing voltage and output voltage.
な対応した条件下にある場合の各出力電流波形と，そ のときの理想的な単結晶モデルにおける理論波形第 8 図(c)を示す。

第 6 図, 第 8 図ともに, ( a ) と ( b ) 図との間にはかな り良い相似性がみられる。第 6 図の比例領域で (b)図 よりむ(a)図の方が電源電圧の影響を多く受け，第 8 図では (b)図よりも ( a ) 図の方が電流波形に丸みが出 ているのは，第5 図(b)の回路では制御電流の $I_{C}$ 変 化に対して磁化特性のこう配が一定なのに対して，第 5 図 (a)の回路では第 4 図に示した磁化特性のこう配 が応力 $\sigma$ の増大と共に小さくなるために, 電源電圧の 波形の影響が現われているためである。

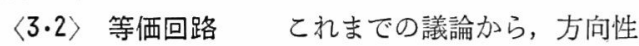
けい素鋼板を使用したリアクトル形ロードセルの等価 回路は第 9 図のように書くことができる。すなわち， 磁心 $A$ は理想的な単結晶磁心であり, 磁心 $B$ は形状 効果により生じる $\phi-I$ 特性のこう配を表わすために わかりやすく分離した磁心であって，乙れらの並列回 路として考えることができる。

磁心 $A$ と磁心 $B$ の特性を合成した磁化特性が第 4 図の磁化特性に等しいという関係加ら，第 9 図に示す $I_{a}$ と $I_{b}$ を求めると次式が得られる。

$$
\begin{aligned}
& I_{a}=l_{1} H_{T} / N_{G} \ldots \ldots . \\
& I_{b}=\left(l_{2}-l_{1}\right) H_{T} / N_{G}
\end{aligned}
$$

(15)式加ら, 磁心 $A$ は磁路長 $l_{1}$ の単結晶磁心と考え

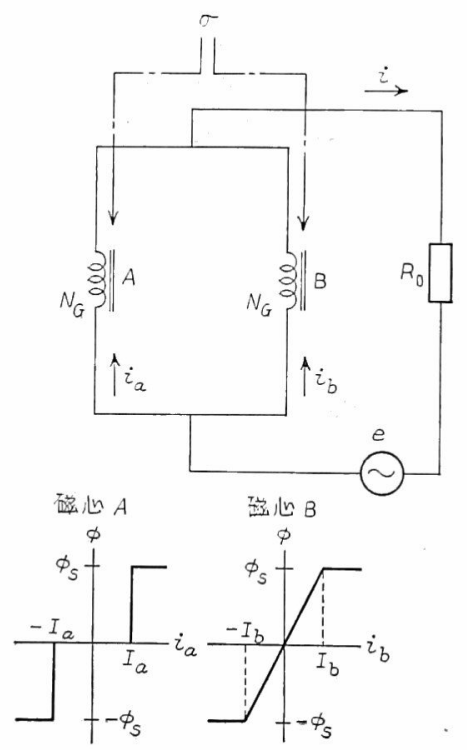

第 9 図リアクトル形ロードセルの等価回路

Fig. 9. Equivalent circuit of a reactor type load cell. 
ることができる。とれに対して，磁心Bは透磁率が応 力に反比例する多結晶性磁心上考えることができる。 ここで，磁心 $B$ の見捇けの透磁率 $\mu=B_{s} /\left(N_{G} I_{b} / l\right)$ は (16)式加ら次のようになる。

$$
\mu=\frac{l}{l_{2}-l_{1}} \cdot \frac{B_{s}}{H_{r}}
$$

磁心の形状が $l_{2} \simeq l_{1}$ の上きには磁心 $A$ が， $l_{2} \gg l_{1}$ の とさには磁心 $B$ が全体の磁化特性を支配するように なる。

〈3.3〉伝達特性第 9 図の等洒回路を使用して, ロードセルの入力でちる応力 $\sigma$ とロードセルの出力で ある回路電流 $i$ との間の伝達特性を求めてみよう。口 ードセルとしては電源電圧変動の影響を受けにくいの が望ましいので，以下では磁心が非飽和状態にある上 し，形状上の関係加 3 種類の場合に分けて取扱うこ 上比する。

（1） $l_{2} \simeq l_{1}$ の場合 (理想的単結晶モデル)

この 場合には，第 9 図の等価回路で磁心 $A$ のみ考虑す 机ば良い。徉って，磁心の非飽和条件加ら比例領域に 㧍ける出力電流 $i_{a}$ の平均值 $I_{m a}$ を求めると次式を得 る。

$$
I_{m a} \equiv I_{a}=\left(l_{1} / N_{G}\right) H_{T}
$$

前に，(8)，(9)式において $H_{T}$ が応力 $\sigma$ に比例する ことが示されているので（18)式はロードセルの出力 電流 $I_{m a}$ が応力。に比例することを表加している。同 時に, 出力電流 $I_{m c}$ が電源電压や周波数に無関保で定 電流出力であることがわかる。定電流出力が得られる ことは単結晶モデルによるリアクトル形ロードセルの 優れた特長で苛って，電源の電圧变動や周波数変動の 影微索受けないという実用上の大きな利点がある。

(18)式が成り立つための比例限界岵可飽和リアクト ル上の相似性から次式で与えられる(13)。

$$
I_{m a} \leq 0.8\left(E / R_{0}\right)
$$

又は

$$
H_{T} \leq 0.8\left(N_{G} / l_{1}\right) \cdot\left(E / R_{0}\right)
$$

ここで, $E:$ 霾源電圧 $e$ の平均值

(19）式は，比例領域をできるだけ広くするには回路

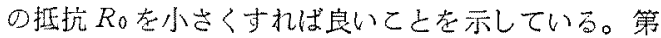
6 图（a）の破線は比例限界を示したものである。

（2） $l_{2} \gg l_{1}$ の場合(多結晶性） 第 9 図の等価回 路に找いて形状效果に上り磁心 $B$ が支眍的になる場 合には，可変インダクタンスとして取扱うことができ 万。磁心 $B$ を流れる電流 $i_{b}$ の平均值 $I_{m b}$ は電源電圧 の平均值 $E$ 及びインダクタンス $L$ 之の間次次のよう な阅停がある。

$$
\begin{aligned}
& I_{m b}=\frac{E}{\omega L V 1+\left(R_{0} / \omega L\right)^{2}} \cdots \\
& L=\frac{\mu \cdot S \cdot N_{C}{ }^{2}}{l}=\frac{B_{S} \cdot S \cdot N_{G}{ }^{2}}{\left(l_{2}-l_{1}\right) H_{T}}
\end{aligned}
$$

但し， $S$ : 磁路の断面皘 $R_{0} \ll \omega L$ の場合には

$$
I_{m b}=\left(\frac{E}{\omega S N_{G} B_{s}}\right) I_{b}=\left(\frac{B_{m}}{B_{s}}\right) I_{b}
$$

ここで， $B_{m}$ : 磁束密度の平均值

すな⿰力口，出力は $R_{0} か ゙ \omega L$ に比較して無視できるほ ビ小さいときはインダクタンス $L$ に反此例し，谜。 て応力 $\sigma$ に比例する。又，電源電圧 $E$ に比例し，周 波数 $\omega$ に反比例することがわかる。

$R_{0}$ が $\omega L$ の大きさに比較して無視できないはど大 きいときは, 応力 $\sigma$ と出力電流 $I_{m b}$ との間の伝達特 性は非線形となり，第 10 図のように上に凸の特性に なる。图中 $\sigma_{R}$ は定格応力を示し，実線加伝達特性， 一点鎖線が雾点と定格点を結ぶ直楾である。乙の場合 のロードセルとしての直線性誤差を求めてみよう。直 線性愦差 $d$ として次式のように定義する。

$$
d \equiv \frac{I_{m b}(\sigma)-\left(\sigma / \sigma_{R}\right) I_{m b}\left(\sigma_{R}\right)}{I_{m b}\left(\sigma_{R}\right)} \times 100(\% \mathrm{FS})
$$

$L_{R}$ を定格岕力 $\sigma_{R}$ のときのインダクタンスとす机ば (24)式は次のように書ける。

$$
d=\left(\frac{\sqrt{1+\left(R_{0} / \omega L_{R}\right)^{2}}}{\sqrt{1+\left(R_{0} / \omega L\right)^{2}}}-1\right) \frac{L_{R}}{L} \times 100
$$

$\hat{\partial} d / \partial L=0$ より $d$ の最大值 $d_{\max }$ を求めると

$$
d_{\max }=\left(\frac{\omega L_{R}}{R_{0}}\right)\left\{\left(1+\frac{R_{0}^{2}}{\omega^{2} L_{R}^{2}}\right)^{1 / 3}-1\right\}^{3 / 2} \times 100
$$

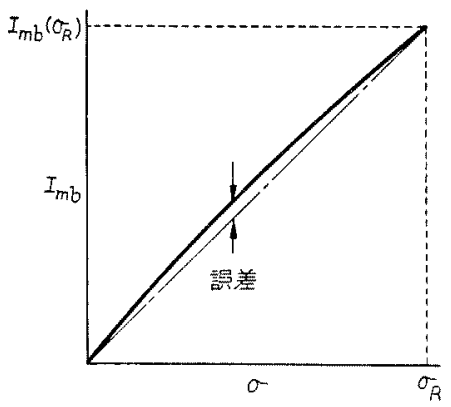

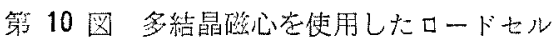
の伝秕特性

Fig. 10. Transfer chaoacteristics of the load cell with polycrystalline magnetic cores. 


$$
\begin{aligned}
d_{\max } & \fallingdotseq \frac{R_{0}{ }^{2}}{3 \sqrt{3 \omega^{2} L_{R}{ }^{2}}} \times 100\left(\frac{R_{0}}{\omega L_{R}} \ll 1\right) \\
& =\frac{R_{0}{ }^{2}\left(l_{2}-l_{1}\right)^{2} H_{T R}{ }^{2}}{3 \sqrt{3} \omega^{2} B_{s}^{2} S^{2} N_{G}{ }^{4}} \times 100 \ldots .
\end{aligned}
$$

ここで, $H_{T R}$ : 定格応力時の $H_{T}$

(27)式加亏， $d_{\max }$ は $\left(R_{0} / \omega L_{R}\right)^{2}$ 亿は状比例して大き くなり，従って直線性䛊差をできるだけ小さくするた わには，定格㐫力時の磁心のインピーダンス $\omega L_{R}$ が 回路抵抗 $R_{0}$ に比較して十分大きくなるように磁心の 寸法 $\left(l_{1}, l_{2}, S\right)$ や卷線数 $(N)$, 励磁周波数 $(\omega)$ などを 決定しなければならない。

（3）一般の場合 単結晶モデル上多結晶性磁心 の縕合せで考えられる一般的な場合の伝達特性は，之 れぞれ単独の場合の結果加ら容易に求められる。単結 晶モデルの場合と多結晶磁心の場合のいずれの場合に 毛回路の抵抗 $R_{0}$ が伝達特性に決定的な影響を持って いることがわかった。すな⿰力口，回路の抵抗 $R_{0}$ は前 者の場合に结伝達特焚の此例限界之関係し，後者の場 合には，伝洼特性そのものの直線性愦差と関原してい る。従って、リアクトル形ロードセルの場合にはでき るだけ回路の抵沉 Ro が小さいととが望まれる。この 場合， $R_{0} \ll \omega L_{R}$ なる条件下で考无ることにす机ば， 伝達特性住(18) 式と(23)式の和として得られる。

$$
I_{m}=I_{m a}+I_{m b}=I_{a}+\left(B_{m} / B_{S}\right) I_{b}
$$

この場合の直線性誤差位近似的に次式で与えられる。

$$
\begin{aligned}
d_{\max }= & \left(1+\frac{I_{a}}{I_{b}} \cdot \frac{B_{s}}{B_{m}}\right) \frac{R_{0}{ }^{2}}{3 \sqrt{3} \omega^{2} L_{R}{ }^{2}} \\
& \times 100(\% \mathrm{FS})
\end{aligned}
$$

(29)式加ら直線性望差を小さくするに法できるだけ $\simeq l_{2}$ とし，加 $R_{0} \ll \omega L_{R}$ にしなけ机ばならないとと がわかる。但し，極端に $l_{1} \simeq l_{2}$ とすること法磁心の柱 の大きさに比㣀して背の高さが高くなるととを意味し 応力经澾上, 不安定になりやすいので注意する必要か 市る。

第 11 图にロードセルの伝達特性の实测洌老示す。 态力が新 $1.5 \mathrm{~kg} / \mathrm{mm}^{2}$ までは伝達特性纪曲りがある が，それ以上ではすぐれた直線性が得られている。小

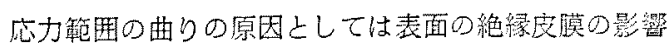
や零応力時の鉄損などが考えられるが定量的には不明 確である。ロードセルとして使用する場合には 2 3 $\mathrm{kg} / \mathrm{mm}^{2}$ のバイアス応力を加元て直線性の良い応力範 因だけを利用する。第 12 因には実用応力範围 2.7 $5.3 \mathrm{~kg} / \mathrm{mm}^{2}$ に打讨る直線性誤差上回路抵抗之の関係

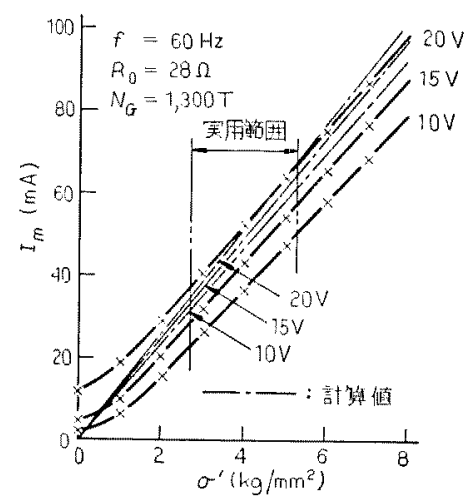

第 11 図ロードセルの伝達特性

Fig. 11. Transfer characteristics of a load cell.

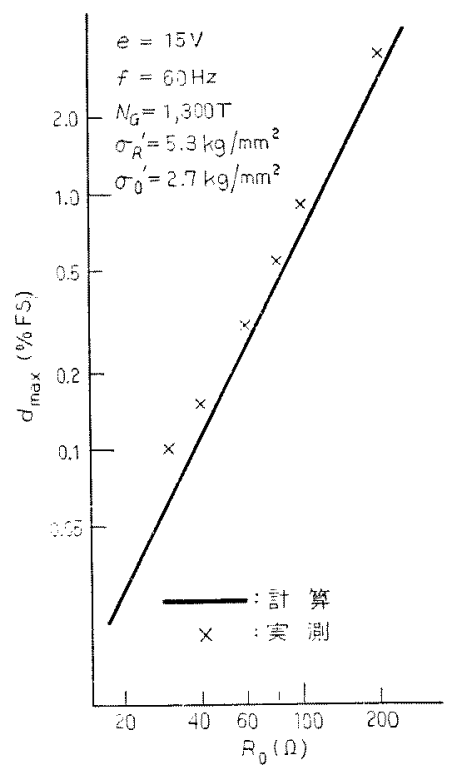

第 12 图 直線性誤蓄と回路抵抗の関係

Fig. 12. Relation between the linearity error and the resistance of the circuit.

䒠測した例走すす実測值が計算結果より少し大き くなっているが，これはバイアス応力の影響によるす のと考えられる。回路抵抗が小さいところでは $0.1 \%$ FS 程度の直線性が得ら机ている。第 11 図, 第 12 図 の実駼汇はいずれす $\gamma=0^{\circ}$ の磁心を使用している。

ロードセルとして最も基本的な特性である直線性の 愦差仙回路抵抗の大きさに，大きく依存することがわ 加たが，醷心に一様な応力を加えることも重要で， そのため沉応力伝遘譏構がいるいる工坴されている。 


\section{4. むすび}

万向性けい素鋼板の外部応力に上る磁化曲線变化の 解析を行ない，之の結果之磁心の形状效果之を考慮し てリアクトル形ロードセルの等洒回路を作り，これか ら応力と出力との間の伝達特性及び直線性誤差につい て解析を行势った。

その結果，方向性けい素鍋板に対する応力の関係が 普通の可飽和リアクトルに括ける制御電流に対応して おり，雨者は回路的汇同様な取扱いができるととがわ 加った。又, 実際の磁心においては形状効果により磁 心の見掛けの透磁率が応力と共に減少するようになる たぬ，ロードセルの等価回路は単結晶磁心と多結晶性 磁心の並列回路として表わされることを示した。

ロードセルの直線性誤差は，主として回路抵抗 $R_{0}$ と定格荷垔時の磁心のインダクタンス $\omega L_{R}$ 上により 決定され， $\left(R_{0} / \omega L_{R}\right)^{2}$ に比例することが明らかとなっ t。
リアクトル形ロードセルに関する解析結果は，他の 㗪気式ロードセルの趿作を考察する上でも，最む基本 となるあのである。

最後に，本研究任終始御援助を媔いた安川電機製作

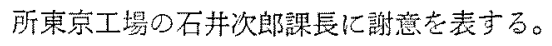

(昭和 50 年 3 月 13 日受付, 同 51 年 2 月 10 日再受付)

\section{文献}

(1) O. Dahle: 特訣昭 31-495

(2) O. Dahle: Proc. Intermag. conf 13, 2 (1963)

(3) 平塚: 特許 1 照 42-16030

（4）細江 - 松林: 計测之制御 5，11，pp. 47(昭 41)

(5) 後藻: 昭 45 䉓気四学会連大 No. 326

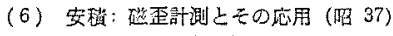

(7) R.M. Bozorth: Ferromagnetism p. 617 (1951)

（8）菊池：磁歪振動之超音波（炤 37)

(9) K.K.ナミトコフ:エレクトロテクニカ 38, 2, p.50(阫42)

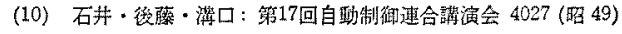

(11) 茂木: 碳気增㨽器 p.14 (昭 32)

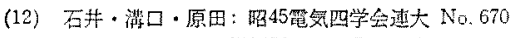

(13) 山村 - 原田: 础绿增辐器 pp. 117 (昭 34) 